\title{
Nickel nanoparticles supported by commercial carbon paper as a catalyst for urea electro-oxidation
}

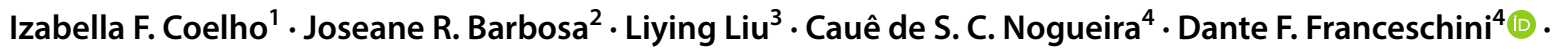 \\ Eduardo A. Ponzio ${ }^{2}$. Júlio César M. Silva ${ }^{2} \cdot$ Yutao Xing ${ }^{4}$ (1)
}

Received: 7 July 2020 / Accepted: 31 August 2020 / Published online: 8 September 2020

(c) The Author(s) 2020

\begin{abstract}
Nickel nanoparticles supported by commercial carbon paper (CP) are prepared by pulsed laser deposition with deposition time of 3,6, and $12 \mathrm{~min}$ as a catalyst for urea electro-oxidation. The surface conditions and the morphologies of the prepared electrodes have been characterized by Raman spectroscopy, scanning electron microscopy, and transmission electron microscopy. Urea electro-oxidation reaction in $\mathrm{KOH}$ solution on the $\mathrm{Ni} / \mathrm{CP}$ electrodes is investigated by cyclic voltammetry and chronoamperometry. The results show that the electrode with less Ni nanoparticle agglomeration shows higher peak current density, which was achieved in the 3 min deposition samples when normalized by electroactive surface areas. However, the highest current normalized by the area of the carbon paper was achieved in the 6 min deposition sample due to the larger quantity of Ni nanoparticles. All the samples show good stability. Our results suggest that the low density, low cost, and environmental friendly $\mathrm{CP}$ can be used as support for Ni nanoparticle as a catalyst for urea electro-oxidation. It thus has great potential for many applications involving urea oxidation, such as wastewater treatments.
\end{abstract}

Keywords Nickel nanoparticles $\cdot$ Carbon paper $\cdot$ Urea electro-oxidation $\cdot$ Catalyst

\section{Introduction}

The generation of clean energy and the wastewater treatment are two major challenges faced and pursued due to the heavy dependence on fossil fuels, non-renewable energy sources, which cause environmental impacts through the greenhouse gas emissions, and the constant contamination of rivers due to the absence of an adequate wastewater treatment [1].

Urea is a substance found in domestic wastewater, as it is the main component of human and animal urine, containing about $2-2.5 \mathrm{wt} \%$ of urea [2,3], and in industrial effluents, such as a large amount of urea-rich wastewater generated by the process of urea synthesis as agricultural fertilizer and animal feed additive $[4,5]$. When these effluents are discharged into rivers without treatment, they can generate serious environmental contamination and human health problems because urea, despite being non-toxic, can naturally decompose into toxic ammonia and others nitrogenous pollutants $[1,6-8]$. The treatment of wastewater through traditional methods, such as aeration tanks, presents itself as a great consumer of energy [9]. Urea is conventionally treated by nitrification and denitrification, which are sophisticated and high energy consuming
Centro de Caracterização Avançada para Indústria de Petróleo (LaMAR/CAIPE), Universidade Federal Fluminense, Niterói, RJ 24210-346, Brazil

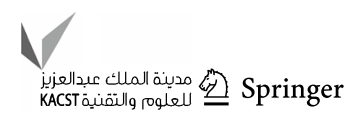


biological processes, generating an excessive cost [7]. As an alternative, urea electro-oxidation has proven to be an effective way for its degradation. Moreover, it is considered as a low-cost technology, dispenses sophisticated equipment and can be applied for long periods of time $[10,11]$. The conversion occurs from the following electrochemical oxidation reactions $[7,12,13]$ :

$$
\begin{aligned}
& \text { Anode: } \mathrm{CO}\left(\mathrm{NH}_{2}\right)_{2}+6 \mathrm{OH}^{-} \rightarrow \mathrm{N}_{2}+5 \mathrm{H}_{2} \mathrm{O}+\mathrm{CO}_{2}+6 \mathrm{e}^{-} \\
& \text {Cathode: } 6 \mathrm{H}_{2} \mathrm{O}+6 \mathrm{e}^{-} \rightarrow 3 \mathrm{H}_{2}+6 \mathrm{OH}^{-} \\
& \text {Overall: } \mathrm{CO}\left(\mathrm{NH}_{2}\right)_{2}+\mathrm{H}_{2} \mathrm{O} \rightarrow \mathrm{N}_{2}+3 \mathrm{H}_{2}+\mathrm{CO}_{2}
\end{aligned}
$$

Several catalysts such as metals $(\mathrm{Ni}, \mathrm{Fe}, \mathrm{Cu}, \mathrm{Mn}, \mathrm{Zn}$, $\mathrm{Pt}$, etc.), metal oxides and metal free have been widely studied over the years in electrochemical processes [14]. Among them, nickel (Ni) is extensively used because of its important characteristics such as its large abundance in nature, low cost (non-precious metal) and low toxicity [15]. Additionally, Ni electrocatalysts demonstrate excellent catalytic activity for urea electro-oxidation in alkaline solutions. As presenting good chemical stability [12], high ductility, good thermal conductivity, and considerable electrical conductivity [15], Ni electrocatalysts are usually used as anodic electrodes in the process [7]. However, several factors can influence the catalytic activity of a metal, such as the metal support interaction $[16,17]$. In order to increase the stability of the material and increase the area of exposed active sites of Ni catalysts, several authors have studied carbon-based supports, such as carbon nanotubes [18, 19], graphene [19, 20], and carbon fiber paper (CP) [21, 22] allowing an increase in activity and catalytic performance [23]. CP can be used for the electrochemical application, such as in fuel cells and electrocatalysts, acting as microporous layer support for catalysts. Its characteristics are the efficient transportation of gases and liquids, good thermal, and electrical conduction in high corrosive environments and high-temperature conditions [24-26]. For these reasons, CP is a suitable option as support for Ni nanoparticles for electrocatalysis applications.

There are several techniques for the production of $\mathrm{Ni}$ nanoparticles [15], which may include synthesis by thermal decomposition [27], chemical reduction [28], microemulsion [29], sol-gel method [30], sonochemical synthesis [31], Pulsed Laser Deposition (PLD) [32], etc. Among the mentioned techniques, PLD is known for its good control of the distribution and particle size during its production [33]. This technique is based on the ablation of a Ni target induced by a high power pulsed laser inside the PLD chamber, that can occur in vacuum conditions or in the presence of a background gas. The species that suffer ablation are deposited on the support surface [34].

In this work, commercial $\mathrm{CP}$, which is cheap and easy to obtain, was tested as support for Ni nanoparticles synthesized by using the PLD technique. Optimizing the balance between the Ni loading quantities and catalytic behavior for the purpose of real applications is another main goal of this study. The support and the synthesized catalysts were characterized by the techniques of Raman spectroscopy, scanning electron microscopy (SEM), and transmission electron microscopy (TEM). The electrocatalytic activity of the materials towards the urea electro-oxidation reaction (UER) in alkaline medium was evaluated using cyclic voltammetry (CV) and chronoamperometry (CA) measurements.

\section{Experimental}

\section{Plasma treatment of carbon paper surface}

The original Teflon treated CP was obtained from Carbon Paper AvCarb. The surface of CP is highly hydrophobic and hence is not suitable for the applications of the current study. To improve the contact between the $\mathrm{CP}$ surface and the reaction solution, the $\mathrm{CP}$ was treated with ammonia plasma in a vacuum chamber with a base pressure of $\sim 2 \times 10^{-2}$ Torr. Ammonia plasma etching has several advantages over air plasma etching or chemical etching: it removes fluorine more efficiently [35], etches the surface more homogeneously, and no chemical residues on the highly porous $\mathrm{CP}$. For plasma etching, a piece of $\mathrm{CP}$ with a dimension of $10 \mathrm{~cm} \times 2 \mathrm{~cm}$ was mounted perpendicular to the sample holder of the plasma chamber with half of it $(10 \mathrm{~cm} \times 1 \mathrm{~cm})$ covered by Al plates. Plasma etching was performed with the $\mathrm{CP}$ mounted on the cathode of a capacitively coupled RF chamber, with a $\mathrm{NH}_{3}$ plasma discharge. The discharge was established at 0.10 Torr $\mathrm{NH}_{3}$ and $-300 \mathrm{~V}$ self-bias (37 W RF power) for $20 \mathrm{~min}$. The illustration of the process and a plasma-etching image can be found in Fig. 1. After plasma-etching, a small piece of the $\mathrm{CP}$ was tested by dropping water onto the surface. The treated CP was then cut into pieces with a dimension of $2 \mathrm{~cm} \times 0.5 \mathrm{~cm}$ as support of Ni nanoparticles. The hydrophilic area of each sample was $1 \mathrm{~cm} \times 0.5 \mathrm{~cm}$.

\section{Nanoparticles production}

The hydrophobic part of the final CP support was covered by a piece of kapton tape and was mounted onto the substrate holder of PLD system for Ni deposition. The background pressure of the PLD system was $\sim 10^{-6}$ Torr. The Ni nanoparticles were deposited from pure $\mathrm{Ni}(99.99 \%)$ target onto the hydrophilic part of the $\mathrm{CP}$ in the presence of an $\mathrm{Ar}$ background atmosphere (1.0 Torr) at room temperature. The 
Fig. 1 Left: Illustration of the electrode preparation. Upper right: carbon papers under plasma etching. Lower right: Wetting test for the etched and non-etched CP surfaces by drooping water on

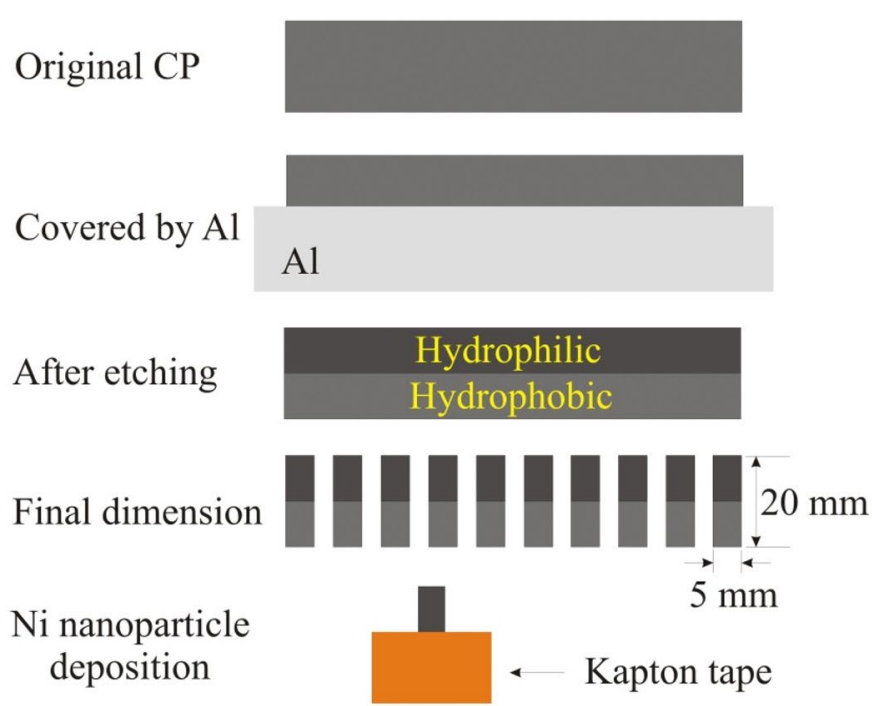

target ablation was done using the first harmonic (1064 nm wavelength) of a pulsed Nd:YAG laser with $0.12 \mathrm{~J} / \mathrm{mm}^{2}$ energy density, $7 \mathrm{~ns}$ pulse duration, and $10 \mathrm{~Hz}$ repetition rate. The laser beam was focused onto the Ni target with an incidence angle of $45^{\circ}$ and the ablated $\mathrm{Ni}$ atoms expanded in the direction of the substrate, with a fixed $3.5 \mathrm{~cm}$ distance from the target. Samples with deposition time of 3, 6 and 12 min were prepared to obtain the different amount of $\mathrm{Ni}$ nanoparticles on the $\mathrm{CP}$ support and were named as $3-\mathrm{Ni} /$ $\mathrm{CP}, 6-\mathrm{Ni} / \mathrm{CP}$, and $12-\mathrm{Ni} / \mathrm{CP}$, respectively.

\section{Characterization}

The morphology and thickness of the samples were investigated by using field-emission scanning electron microscope (SEM: JEOL JSM 7100F) and field-emission high-resolution transmission electron microscopy (HRTEM. JEOL JEM 2100F). The chemical composition and electronic structure of the products were characterized by Raman spectroscopy (Witec alpha 300R Raman microscope, with $532 \mathrm{~nm}$ wavelength excitation) and energy-dispersive X-ray spectroscopy (EDS).

\section{Electrochemical measurements}

Electrochemical measurements were carried out at room temperature using a $\mu$ Stat 400 bipotentiostat/galvanostat (Metrohm DropSens), by using a three-electrode electrochemical cell, with a platinum foil as the counter electrode, $\mathrm{Hg} / \mathrm{HgO}$ as reference electrode and the $\mathrm{CP}$ with nickel particles as the work electrode. $\mathrm{CV}$ experiments were performed in $1 \mathrm{~mol} \mathrm{~L}^{-1} \mathrm{KOH}$ at a scan rate of $50 \mathrm{mV} \mathrm{s}^{-1}$ from 0.0 to $0.65 \mathrm{~V} v s \mathrm{Hg} / \mathrm{HgO}$. Prior each experiment $\mathrm{N}_{2}$ was bubbled for $15 \mathrm{~min}$, and ten consecutive cycles were recorded for each material. Five cycles $\left(10 \mathrm{mV} \mathrm{s}^{-1}\right)$ were recorded from $0.0 \mathrm{~V}$ and $0.75 \mathrm{~V}$ vs $\mathrm{Hg} / \mathrm{HgO}$ in $1 \mathrm{~mol} \mathrm{~L}^{-1}$ $\mathrm{KOH}+0.33 \mathrm{~mol} \mathrm{~L}^{-1}$ urea solution. The concentration of $0.33 \mathrm{M}$ urea was used during the experiment to simulate the concentration of urea in urine waste and it is the urea concentration usually studied [2-4, 10, 36-39]. In both cases, the last cycle is shown. Chronoamperometric experiments were carried out at $0.55 \mathrm{~V}$ vs $\mathrm{Hg} / \mathrm{HgO}$ for $60 \mathrm{~min}$. The current from the urea electro-oxidation process was normalized by the electroactive surface areas (ESA), estimated according Eq. 4.

$\mathrm{ESA}=Q / q$

where $Q$ is the charge required to reduce $\mathrm{Ni}^{3+}$ to $\mathrm{Ni}^{2+}$ [NiOOH to $\left.\mathrm{Ni}(\mathrm{OH})_{2}\right]$, which can be calculated from the cyclic voltammograms in electrolyte support. In Eq. 4, $q$ is the charge related to the formation of a monolayer of $\mathrm{Ni}(\mathrm{OH})_{2}$ from $\mathrm{NiOOH}$ that involves one electron transfer and the value can be taken as $257 \mu \mathrm{C} \mathrm{cm}^{-2}$ [10, 40, 41]. The procedure to determine the ESA was similar to that one reported elsewhere $[10,36]$. However, the difference is that the obtained ESA was not normalized by nickel loading in the electrode like in the literature $[10,36]$. The results were also normalized by electrode geometric area (GSA) of the work electrode.

\section{Results and discussion}

As can be seen from Fig. 1, the CP surface has turned from hydrophobic to hydrophilic by the $\mathrm{NH}_{3}$ plasma-etching and then became suitable as catalyst support for electrocatalysis applications. To investigate the surface modification, the original and plasma-treated $\mathrm{CP}$ was characterized by using Raman spectroscopy, with the results being shown in Fig. 2 . 


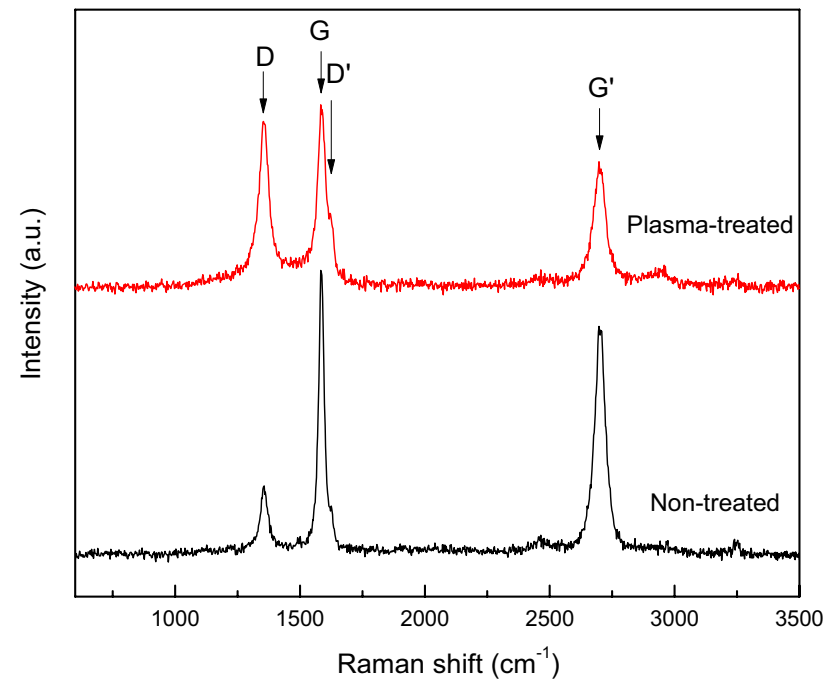

Fig. 2 Raman spectra of the original and plasma-etched carbon paper, showing the main Raman features of graphite: the $D, G, D^{\prime}$ and $G^{\prime}$ bands
The spectrum of the original CP showed clearly the most prominent features of graphite: the $\mathrm{G}$ band at $1582 \mathrm{~cm}^{-1}$, the $\mathrm{D}$ band at $\sim 1350 \mathrm{~cm}^{-1}$, the $D^{\prime}$ band at about $1620 \mathrm{~cm}^{-1}$ and the $G^{\prime}$ band at $\sim 2700 \mathrm{~cm}^{-1}$ [42]. The $G$ band is associated with a doubly degenerate phonon mode for $\mathrm{sp} 2$ carbon networks. The $D$ and $D^{\prime}$ bands are related to defects, and thus being usually absent in the spectrum of highly crystalline graphite. The $G^{\prime}$ band is a feature of $D$ band overtone in different kinds of graphitic materials. The integrated intensity ratio $I_{D} / I_{G}$ for the $D$ band and $G$ band is usually applied for analyzing the number of defects in graphitic materials [43]. A relatively weak $D$ band is clearly observed for the original $\mathrm{CP}$ in Fig. 2, which indicates that the $\mathrm{CP}$ is constructed by graphite fibers with a small number of defects. After plasmaetching, the intensity of $D$ band significantly increased, suggesting a large quantity of defect generation; other bands were not obviously modified.

Detailed microstructure studies were performed for the original and plasma-etched CP. As can be seen from Fig. 3, the $\mathrm{CP}$ is constructed by carbon fibers with diameters in the range of 5-10 $\mu \mathrm{m}$ and possesses plenty of pores and voids. From the back-scattered electron image of the original CP
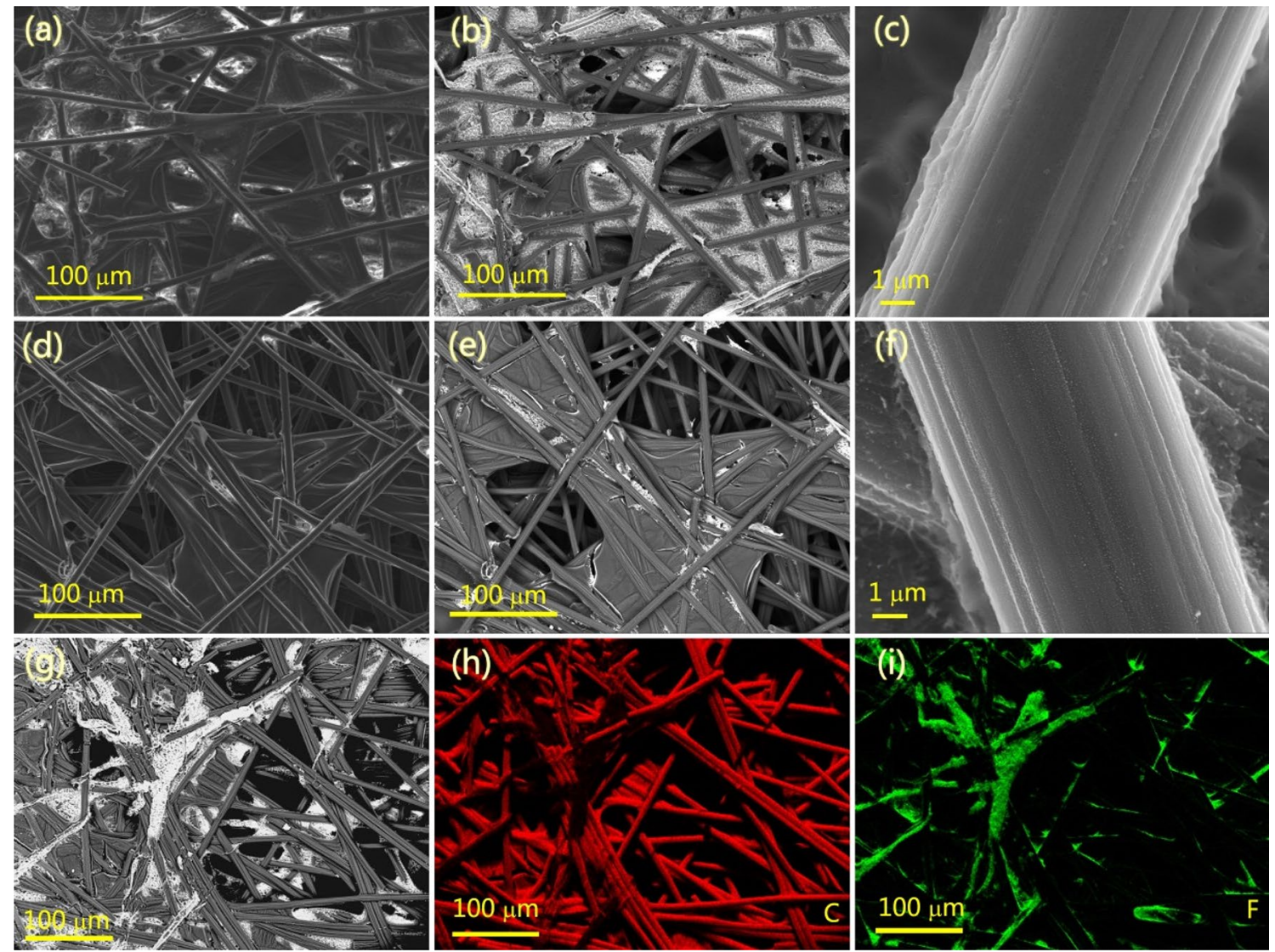

Fig. 3 a Low magnification secondary electron image, b low magnification back-scattered electron image and $\mathbf{c}$ high resolution SEM images of the original CP. $\mathbf{d}, \mathbf{e}$ and $\mathbf{f}$ are the corresponding images of the plasma-treated CP. g A low-mag back scattered SEM image of the original $\mathrm{CP}$ and the elemental mapping with EDS for $\mathbf{h}$ carbon and $\mathbf{i}$ fluorine 
(Fig. 3b), a layer with a higher brightness than the carbon fibers appeared. Since the back-scattered electron image gives atomic mass contrast and the surface of the CP is hydrophobic, the brighter layer might be fluorine rich and is responsible for the hydrophobic property. The EDS analysis is shown in Fig. 3g-i confirmed that the original CP fibers are composted by purely carbon and the bright layer is rich of fluorine. No other elements with a concentration higher than the level of contamination were observed. The first effect of plasma-etching process is fluorine removal, which is clearly shown in Fig. 3d, e. Most of the fluorine has been removed by $\mathrm{NH}_{3}$ plasma and only few of them is left in the sharp corners, where was more difficult for plasma generation. Quantitative analyses of the average EDS spectra obtained from the elemental mapping results for original and plasma-treated CP clearly demonstrated a decrease of fluorine from $\sim 30 \mathrm{wt} \%$ to $\sim 9 \mathrm{wt} \%$ after plasma etching (as shown in the supplementary information). The absence of nitrogen signal on the EDS spectrum for the treated $\mathrm{CP}$ suggested the nonexistence of residual ammonia on the $\mathrm{CP}$ surface. The significant decrease of fluorine concentration on the surface resulted in the transformation of the $\mathrm{CP}$ surface from hydrophobic to hydrophilic. Another effect of the plasma-etching is the roughness increase on the surface of each carbon fiber. From Fig. 3c we can see that the carbon fiber has a very flat surface. After plasma-etching, however, abundant nano-sized points appeared and were homogeneously distributed on the surface of the carbon fibers. Higher resolution images can be found in the supplementary information to show it more clearly. The result is in well agreement with the conclusion of Raman spectra, which suggested a large number of defect generation due to plasma-etching. Both transformations from a hydrophobic to a hydrophilic surface and surface roughness increase greatly benefit the catalytic behavior, while the former increases the contact of the CP surface with a solution and the latter enhances the specific surface area.

A detailed microstructure study for the Ni deposited $\mathrm{CP}$ has been done with SEM and the images are shown in Fig. 4. The 3-Ni/CP sample showed that many nano-sized particles appeared on the surface of each nanofiber. The high-resolution image (Fig. 4b) reviled that the bright nanoparticles in Fig. 4a are non-regular and are constructed by smaller sized particles $(<100 \mathrm{~nm})$. The back-scattered electron image (Fig. 4c) clearly shows atomic mass contrast, indicating that the nanoparticles are composted by heavier element
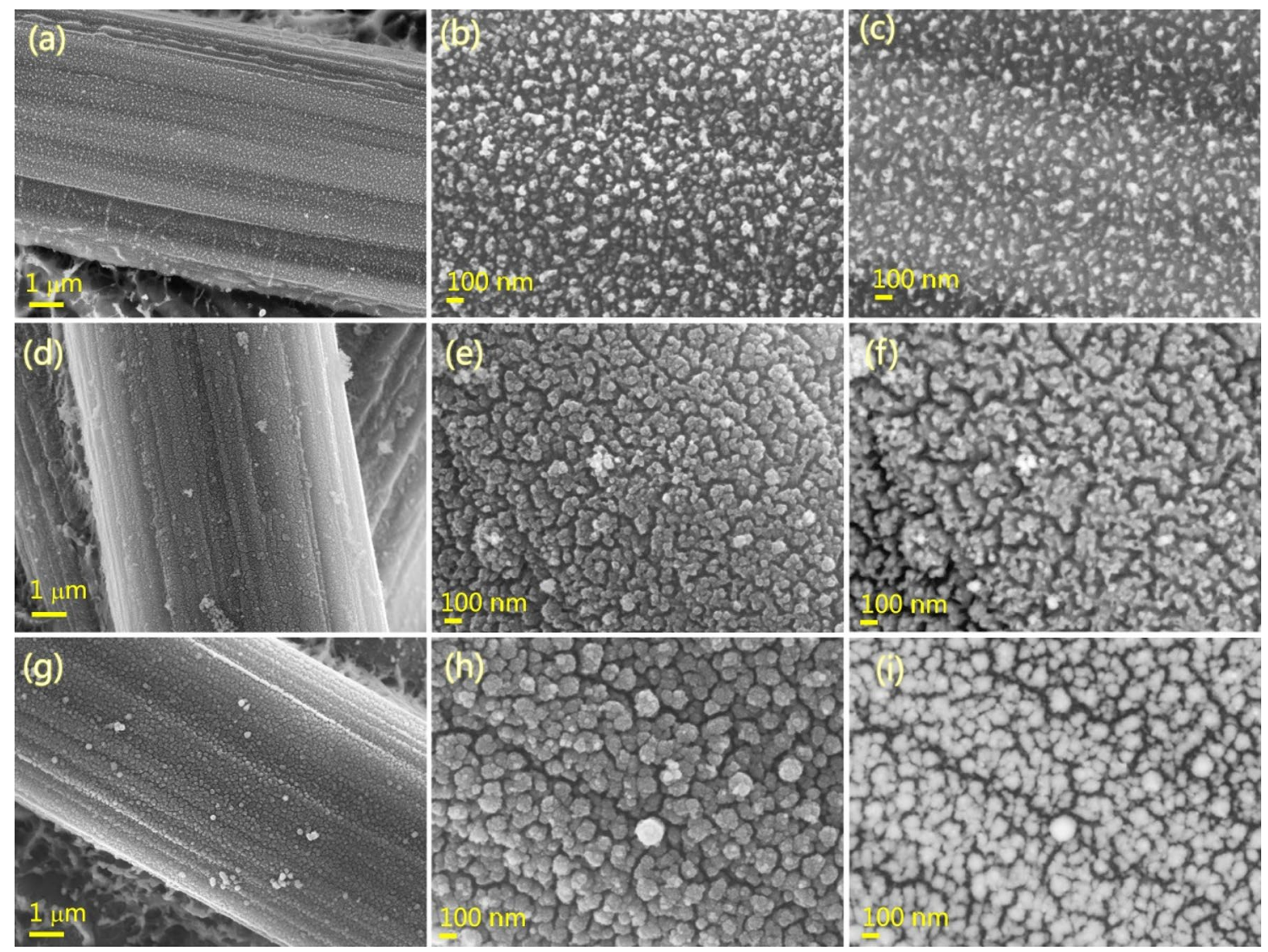

Fig. 4 a Low magnification secondary electron image, $\mathbf{b}$ high magnification secondary electron image and $\mathbf{c}$ high magnification back-scattered electron image of the $3-\mathrm{Ni} / \mathrm{CP}$. $\mathbf{d}-\mathbf{f}$ are the corresponding images of the $6-\mathrm{Ni} / \mathrm{CP}$ and $\mathbf{g}-\mathbf{i}$, of $12-\mathrm{Ni} / \mathrm{CP}$

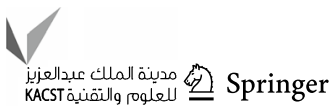


than $\mathrm{C}$ and in this work, it is apparently Ni. With 3 min of $\mathrm{Ni}$ deposition, the $\mathrm{Ni}$ nanoparticles were well dispersed on $\mathrm{CP}$ surface without large agglomerations. After $6 \mathrm{~min}$ of $\mathrm{Ni}$ deposition, more agglomeration of $\mathrm{Ni}$ nanoparticles occurred. Moreover, the nanoparticles started to connect with each other and formed bigger patterns. With a backscattered electron image, one can still see the low-density morphology and each of the bigger patterns was in fact an assembly of many smaller nanoparticles. The mean size of the agglomerated nanoparticles is higher than of the materials prepared with $3 \mathrm{~min}$ of $\mathrm{Ni}$ deposition, however, is still less than $100 \mathrm{~nm}$, as can be seen from Fig. 4e. With even more Ni nanoparticles deposited (12 min), the size of the agglomerations significantly increased, with a mean value of about $200 \mathrm{~nm}$. The small-sized nanoparticles in Fig. 4c, $\mathrm{f}$ are hardly seen and instead, much bigger and condensed particles appeared in Fig. 4i.

Figure $5 \mathrm{a}, \mathrm{b}$ show a side-view of the deposited $\mathrm{Ni}$ layer on top of one fiber for sample 12-Ni/CP. One can see that the agglomerated nanoparticles have columnar structure with the height of several hundred nanometers. Almost all the surface of the CP is covered by Ni. Smaller sized nanoparticles still can be seen at the border of the Ni layer and C fiber. Although from the back-scattered electron images we can conclude that the deposited nanoparticles might be $\mathrm{Ni}$, it needs to be proved by EDS. Figure 5c-f show the elemental mapping results of Ni by EDS for the sample 12-Ni/CP. The $\mathrm{Ni}$ distribution in the low-magnification mapping (Fig. 5d) perfectly correspondents to the structure and morphology of the CP as shown in Fig. 5c. The result indicates that $\mathrm{Ni}$ nanoparticles are deposited homogeneously on the surface. The black areas in Fig. 5d do not mean the absence of Ni, but less detection of Ni X-ray signal. At those places, the Ni nanoparticles were deposited to the deeper part of the $\mathrm{CP}$ and due to the shape effect, X-ray photons from $\mathrm{Ni}$ exited by the electron beam hardly reach the detector. The high resolution mapping of Ni element in Fig. $5 \mathrm{f}$ shows clearly that the agglomerations of the particles are $\mathrm{Ni}$.

The SEM images suggest that the Ni layer deposited on CPs is constructed by nanoparticles with size much smaller than that of the patterns. With only SEM, one cannot get detailed size and microstructure of the Ni nanoparticles. In order to obtain this information, one sample has been prepared by depositing $\mathrm{Ni}$ nanoparticles onto a $\mathrm{Cu}$ grid with $\mathrm{C}$ support for less than $1 \mathrm{~min}$ and studied by using HRTEM with results shown in Fig. 6. From the low magnification image, we can see that the Ni nanoparticles have sphericalshape and were homogeneously deposited on the surface. The mean diameter of the nanoparticles is about $3.5 \mathrm{~nm}$ with a very narrow size distribution (width at half maximum: $\sim 1.5 \mathrm{~nm}$ ). The high-resolution image in Fig. 6b demonstrates a crystalline microstructure for the particles. During PLD process, the nanoparticles were formed before they were deposited onto the substrate, and their size depends only on the gas pressure in the chamber. Since the same pressure and distance from the target to the substrate were
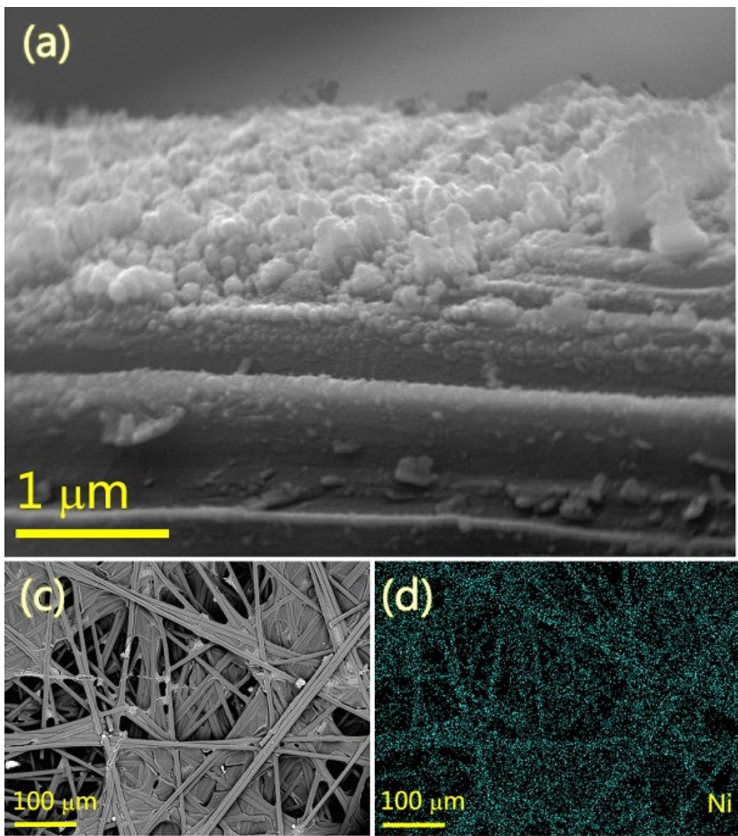

Fig. 5 a Side-view secondary electron image and b back-scattered electron image of the deposited Ni nanoparticles for 12-Ni/CP. c Low magnification secondary electron image and elemental mapping with

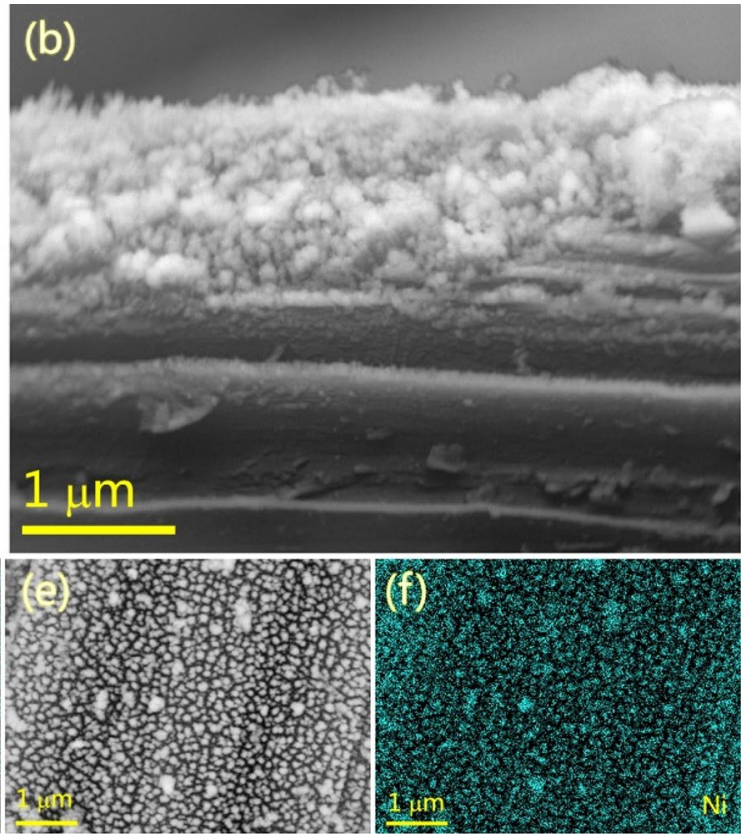

EDS for d Ni. e High magnification back-scattered electron image and elemental mapping with EDS for $\mathbf{f} \mathrm{Ni}$ 

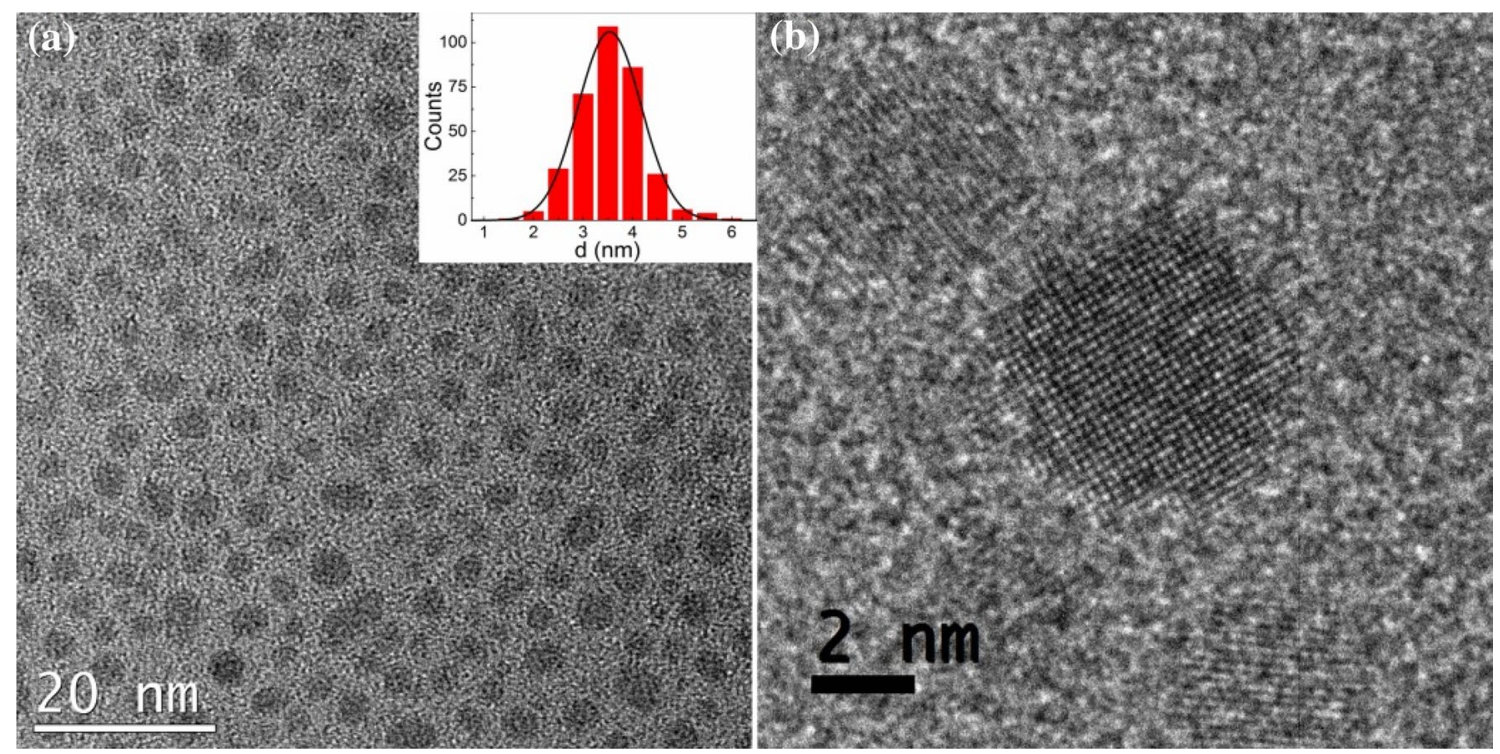

Fig. 6 a Low magnification image of Ni nanoparticles. Inset shows the size distribution of the particles, b HRTEM image of Ni nanoparticles

used for all the three samples in this work, the Ni nanoparticles in the three samples are then similar. The Ar molecules in the chamber play a role not only in the formation of $\mathrm{Ni}$ nanoparticles but also in decreasing their velocity. The Ni nanoparticles with less kinetic energy deposited on the $\mathrm{CP}$ surface have much lower impact and hence, resulted in the formation of less dense material, namely, columnar structure. In contrast, it forms a thin film in a vacuum (much lower pressure) and extremely low-density nanofoam in much higher pressure [44]. X-ray photoelectron spectroscopy (XPS) experiments are of high interest to exam the possible oxidation of $\mathrm{Ni}$ nanoparticles after the sample being removed from the vacuum chamber.

The CV curves of 3-Ni/CP, 6-Ni/CP and 12-Ni/CP electrocatalysts in $1 \mathrm{~mol} \mathrm{~L}^{-1} \mathrm{KOH}$ in the potential range of $0.0 \mathrm{~V}$ to $0.65 \mathrm{~V}$ are shown in Fig. 7. The shape of the CVs is in agreement with nickel catalysts behavior reported in the same experimental condition of the current study [2, 45]. The characteristic redox feature of nickel can be seen in CVs. The peak in the forward scan corresponds to the $\mathrm{Ni}^{2+}$ oxidation to $\mathrm{Ni}^{3+}\left[\mathrm{Ni}(\mathrm{OH})_{2}\right.$ to $\left.\mathrm{NiOOH}\right]$ and the peak in the backward scan is related to the $\mathrm{Ni}^{3+}$ reduction to $\mathrm{Ni}^{2+}$ $[2,36]$. It is important to point out that $\mathrm{NiOOH}$ is the phase responsible for urea electro-oxidation, and not $\mathrm{Ni}(\mathrm{OH})_{2}[2$, 37]. As can be seen, the current related to the nickel oxidation and reduction process increases from the material $3-\mathrm{Ni} / \mathrm{CF}$ to the $12-\mathrm{Ni} / \mathrm{CF}$, which might be related to a higher amount of nickel deposited on the $\mathrm{CP}$ due to longer time deposition. The calculated ESA was $3.81 \mathrm{~cm}^{2}$ for the $3-\mathrm{Ni} /$ $\mathrm{CF}, 6.92 \mathrm{~cm}^{2}$ for $6-\mathrm{Ni} / \mathrm{CF}$ and $7.86 \mathrm{~cm}^{2}$ for $12-\mathrm{Ni} / \mathrm{CF}$. As can be seen, the ESA increases almost twice (82\%) from 3 to 6 min of nickel deposition, which is reasonable. On the other

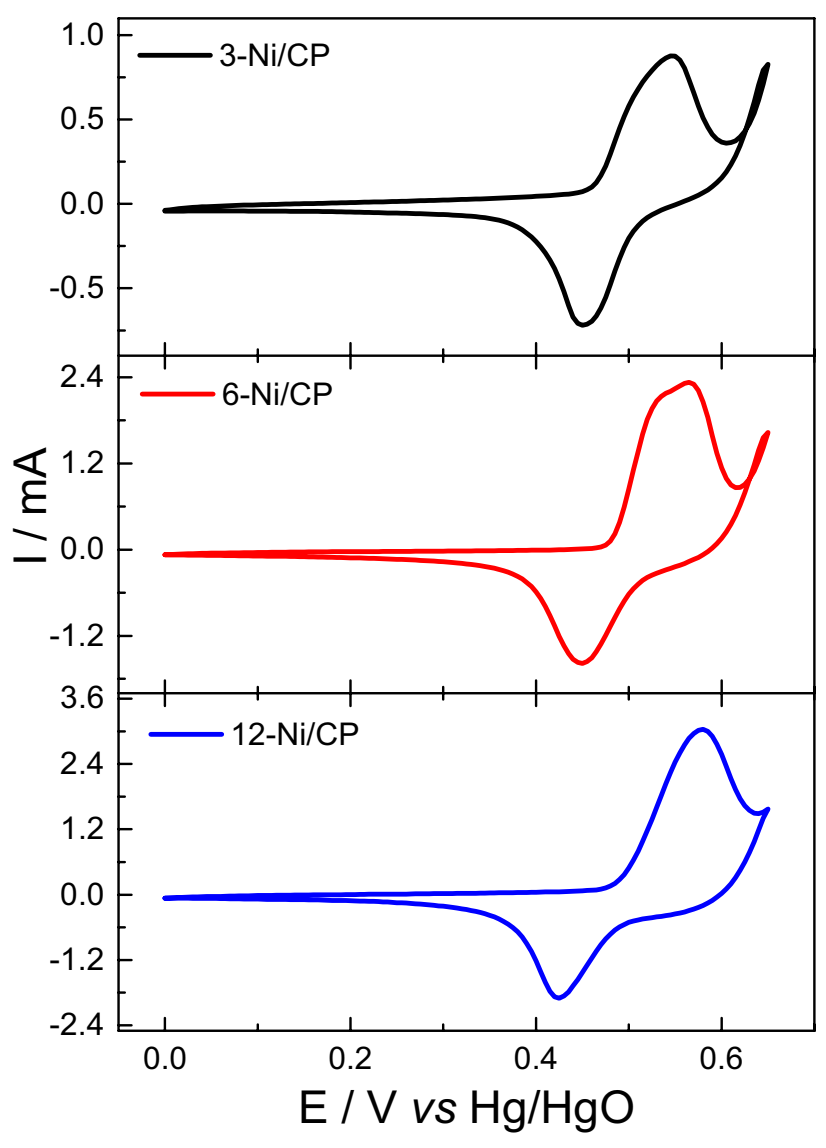

Fig. 7 Cyclic voltammograms of $3-\mathrm{Ni} / \mathrm{CP}, 6-\mathrm{Ni} / \mathrm{CP}$ and $12-\mathrm{Ni} / \mathrm{CP}$ electrocatalysts in $1 \mathrm{~mol} \mathrm{~L}^{-1} \mathrm{KOH}$. Scan rate of $50 \mathrm{mV} \mathrm{s}^{-1}$ 
hand, from 6 to $12 \mathrm{~min}$ of deposition the ESA increases only 13.6\%. As shown in Fig. 4, the mean agglomerated particle size of the materials increased as the time of nickel deposition increases, suggesting a smaller specific surface area for the material prepared with longer time deposition. However, longer time deposition also results in a higher amount of nickel and larger $\mathrm{CP}$ surface coverage. Comparing the two electrodes $3-\mathrm{Ni} / \mathrm{CP}$ and $6-\mathrm{Ni} / \mathrm{CP}$, it is expected that $6-\mathrm{Ni} / \mathrm{CP}$ to have a twice amount of nickel loading than that in $3-\mathrm{Ni} /$ CP since the deposition time doubled, the same comparison can be made for $6-\mathrm{Ni} / \mathrm{CP}$ and $12-\mathrm{Ni} / \mathrm{CP}$. Thus, although the nickel deposition time of $12-\mathrm{Ni} / \mathrm{CP}$ is twice longer than that of $6-\mathrm{Ni} / \mathrm{CP}$, it results in only $13.6 \%$ specific surface area increase, which is related to the larger agglomerated particle sizes observed for $12-\mathrm{Ni} / \mathrm{CP}$ catalyst.

The CV curves of 3-Ni/CP, 6-Ni/CP and 12-Ni/CP electrocatalysts in $1 \mathrm{~mol} \mathrm{~L}^{-1} \mathrm{KOH}+0.33 \mathrm{~mol} \mathrm{~L}^{-1}$ urea in the potential range of $0.0 \mathrm{~V}$ to $0.75 \mathrm{~V}$ are shown in Fig. 8. As can be seen, the onset potential, an important parameter to be extracted from $\mathrm{CV}$ experiments was about $30 \mathrm{mV}$ less positive on $3-\mathrm{Ni} / \mathrm{CF}(0.47 \mathrm{~V})$ than on $6-\mathrm{Ni} / \mathrm{CP}$ and $12-\mathrm{Ni} / \mathrm{CP}$. The decrease of the onset potential is related to a change in the required activation energy for the process, and a suitable catalyst enhances the reaction rate by decreasing the activation energy [46]. It is important to point out that the onset potential starts at the similar potential of the conversion from $\mathrm{Ni}^{2+}$ to $\mathrm{Ni}^{3+}$, confirmed that $\mathrm{NiOOH}$ is the active phase for the urea electro-oxidation reaction [37, 38].

Another import data from the CV experiments is the peak current density. The maximum current density on $3-\mathrm{Ni} / \mathrm{CP}$ was about $8 \%$ higher than on $6-\mathrm{Ni} / \mathrm{CP}$ and $99 \%$ on $12-\mathrm{Ni} / \mathrm{CP}$. Thus, considering both of the peak current density and the

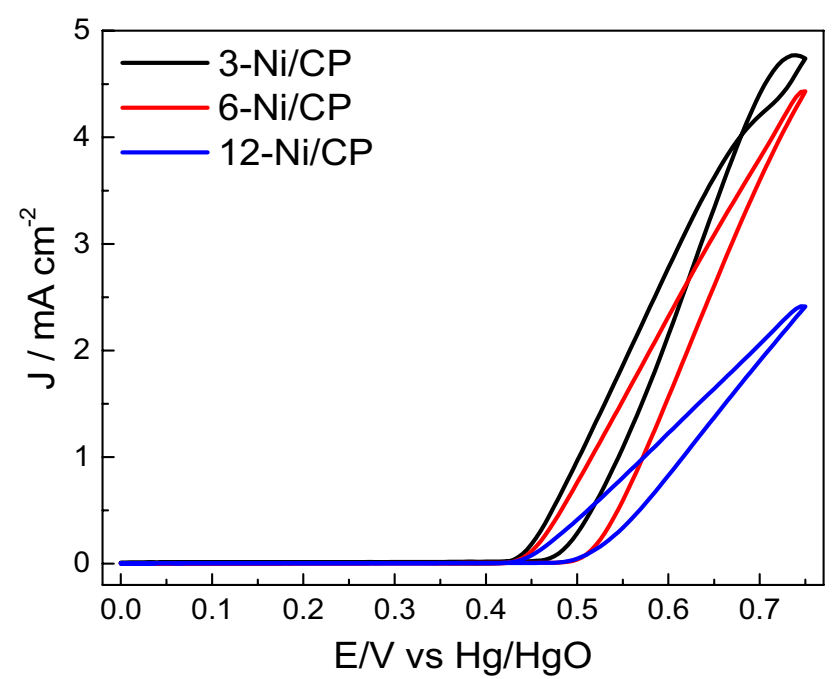

Fig. 8 Cyclic voltammograms of $3-\mathrm{Ni} / \mathrm{CP}, 6-\mathrm{Ni} / \mathrm{CP}$ and $12-\mathrm{Ni} / \mathrm{CP}$ electrocatalysts in $1 \mathrm{~mol} \mathrm{~L}^{-1} \mathrm{KOH}+0.33 \mathrm{~mol} \mathrm{~L}^{-1}$ urea. Scan rate of $10 \mathrm{mV} \mathrm{s}^{-1}$ onset potential, the best results were obtained using $3-\mathrm{Ni} / \mathrm{CP}$ catalyst. However, the maximum current density on $3-\mathrm{Ni} / \mathrm{CP}$ was only about $8 \%$ higher than on $6-\mathrm{Ni} / \mathrm{CP}$. As shown in the SEM images (Fig. 4), the agglomerated nickel particles of $3-\mathrm{Ni} / \mathrm{CP}$ are smaller $(<100 \mathrm{~nm})$ than of the other materials and did not cover the $\mathrm{CP}$ surface completely. On the other hand, for 12-Ni/CP catalyst, the nickel particle mean size is about $200 \mathrm{~nm}$ which forms dense agglomerations, covering almost completely the surface of CP. The nickel particles of $6-\mathrm{Ni} / \mathrm{CP}$ are also more agglomerated than on $3-\mathrm{Ni} / \mathrm{CP}$, but the agglomerated nickel particles are also smaller than $100 \mathrm{~nm}$. It is reported that the materials with at least one dimension smaller than $100 \mathrm{~nm}$ show different properties from the bulk ones, such as, quantum confinement, electrical, magnetic [36]. Nanostructured nickel shows improved catalytic activity towards UER (urea electro-oxidation reaction) if compared with bulk nickel [2, 47]. In this sense, the higher catalytic activity of $3-\mathrm{Ni} / \mathrm{CP}$ followed by $6-\mathrm{Ni} /$ $\mathrm{CP}$ could be related to the smaller particles agglomeration of nickel and better dispersion on the $\mathrm{CP}$ support than of $12-\mathrm{Ni} / \mathrm{CP}$.

Figure 9 shows the chronoamperometric curves in $1 \mathrm{~mol} \mathrm{~L}-1 \mathrm{KOH}+0.33 \mathrm{~mol} \mathrm{~L}^{-1}$ urea on $3-\mathrm{Ni} / \mathrm{CP}, 6-\mathrm{Ni} / \mathrm{CP}$ and $12-\mathrm{Ni} / \mathrm{CP}$ electrocatalysts at $0.55 \mathrm{~V}$ during $60 \mathrm{~min}$. As in $\mathrm{CV}$ experiments, better result was obtained on $3-\mathrm{Ni} / \mathrm{CP}$ catalyst. The current density from urea electro-oxidation on $3-\mathrm{Ni} / \mathrm{CP}$ at the end of $\mathrm{CA}$ experiment was $44 \%$ higher than on $6-\mathrm{Ni} / \mathrm{CP}$ and $133 \%$ on $12-\mathrm{Ni} / \mathrm{CP}$. The slow decay of the current density over time is induced either by the gas bubbles (i.e., $\mathrm{N}_{2}, \mathrm{CO}_{2}$ ) produced from urea electrooxidation or by the blockage of the active site due to the intermediate products $[37,48]$, e.g. CO can cause the deactivation of $\mathrm{NiOOH}$ which is actually the active phase

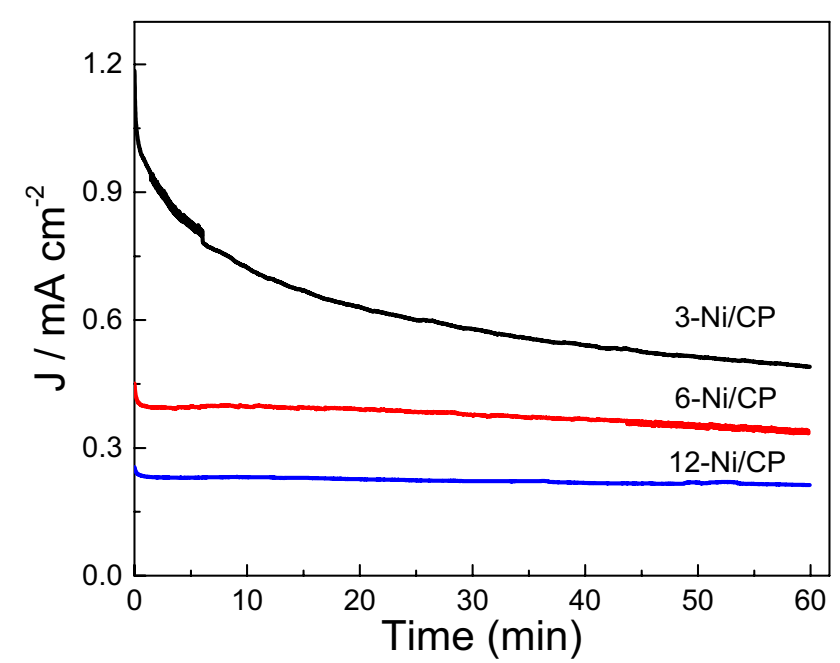

Fig. 9 Chronoamperometric measurements at $0.55 \mathrm{~V}$ vs $\mathrm{Hg} / \mathrm{HgO}$ on $3-\mathrm{Ni} / \mathrm{CP}, 6-\mathrm{Ni} / \mathrm{CP}$ and $12-\mathrm{Ni} / \mathrm{CP}$ electrocatalysts in $1 \mathrm{~mol} \mathrm{~L}^{-1}$ $\mathrm{KOH}+0.33 \mathrm{~mol} \mathrm{~L}^{-1}$ urea 

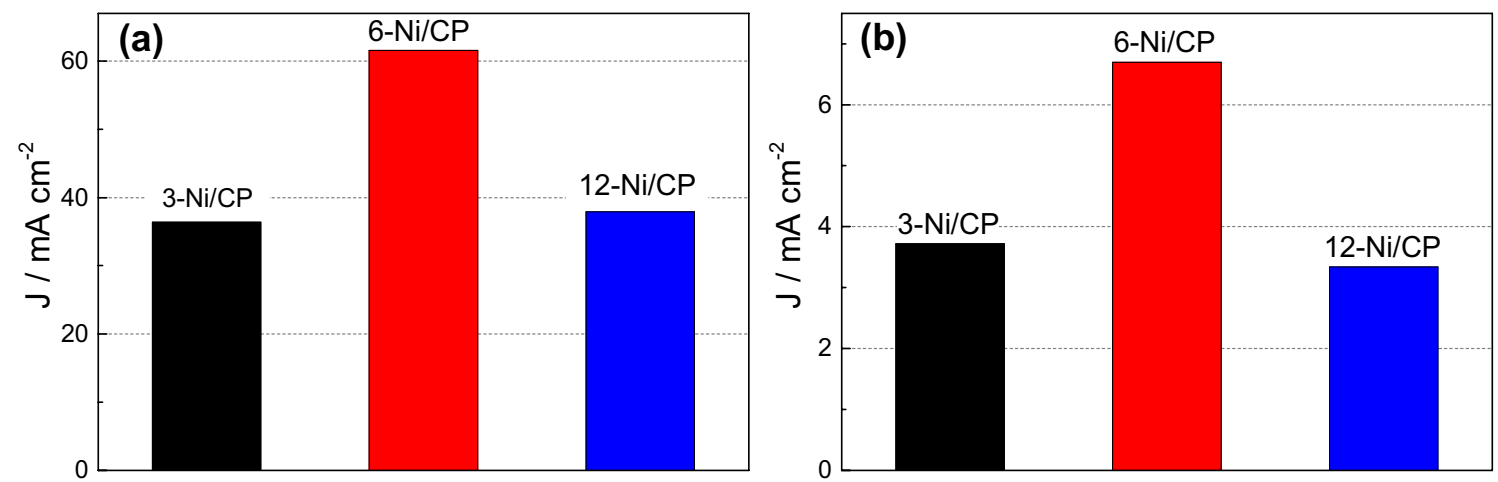

Fig. 10 a Peak current density from urea electrooxidation (from CV experiments), and b current density from CA at 60 min of experiments

to promote urea electro-oxidation [49]. The urea consumption in the electro-oxidation process also influences the drop of current over time $[4,10]$. As can be seen, the current density from urea electro-oxidation on $3-\mathrm{Ni} / \mathrm{CP}$ at the beginning of the process is much higher than on the other two catalysts materials. The higher current density causes faster consumption of urea near to the electrode surface, resulting in a more abrupt decrease of current density in the first minutes of the experiment. Similar behaviours have been reported in the materials showing higher current density from the urea electro-oxidation process $[4,10]$. As discussed in the results from VC (Fig. 8) the smaller size and better dispersion of nickel nanoparticles of 3-Ni/ $\mathrm{CP}$ might be the reason for its superior catalytic activity for urea electro-oxidation compared to the $6-\mathrm{Ni} / \mathrm{CP}$ and $12-\mathrm{Ni} / \mathrm{CP}$.

The results shown in the FigS. 8 and 9 are normalized by ESA. However, considering real applications it would be interesting to normalize the results for the electrode geometric area. The Fig. 10 shows the results of peak current density from urea electro-oxidation on CV experiments (Fig. 10a) and the current density at the end of CA experiments (Fig. 10b). As can be seen, better results were obtained using 6-Ni/CP, considering this normalization. From the results shown in Fig. 10 it is seen that the current density from urea electro-oxidation on $6-\mathrm{Ni} / \mathrm{CP}$ is about $70 \%$ higher than on $12-\mathrm{Ni} / \mathrm{CP}$ and $80 \%$ on $3-\mathrm{Ni} / \mathrm{CP}$. Considering the twice more nickel on $6-\mathrm{Ni} / \mathrm{CP}$ than in $3-\mathrm{Ni} /$ $\mathrm{CP}$ due to doubled deposition time, it would be expected the current density twice higher. However, this relation would be true only if both materials have the same nickel agglomerated nanoparticle sizes but they do not. The SEM analysis and the ESA results suggest that the nickel nanoparticle sizes of 6-Ni/CP are slightly larger. The current density from urea electro-oxidation on $12-\mathrm{Ni} / \mathrm{CP}$ is almost the same with that on $3-\mathrm{Ni} / \mathrm{CP}$ (Fig. 10), which is mainly due to the larger (>200 nm) aggregated nickel nanoparticles in $12-\mathrm{Ni} / \mathrm{CP}$.

\section{Conclusions}

In summary, we employed commercial CP as support of $\mathrm{Ni}$ nanoparticles as catalyst for urea electro-oxidation. The Ni nanoparticles have been prepared by PLD with 3, 6 and $12 \mathrm{~min}$ of deposition time in order to get different Ni loading quantity. The TEM study shows that the Ni nanoparticles have an average size of $3.5 \mathrm{~nm}$ with a narrow size distribution. The SEM results reveal that agglomeration of $\mathrm{Ni}$ nanoparticles occurred in all the samples and they were more agglomerated with longer deposition time. The cyclic voltammograms show that the $3-\mathrm{Ni} / \mathrm{CP}$ sample shows better catalytic activity due to less agglomeration and thus more active sites on the surface of Ni nanoparticles. Lower onset potential has been observed in this sample as well. For real applications, the current normalized by the electrode area is then become important and the experimental results show that the 6-Ni/CP has the best performance, with current density $\sim 60 \%$ higher than the other two samples. The study here shows that $\mathrm{CP}$ can be used as low cost and environmentally friendly catalyst support and electrodes with intermediate $\mathrm{Ni}$ loading quantity might be of interest for real applications of urea electro-oxidation.

Acknowledgements The authors gratefully acknowledge FAPERJ for the support with grant numbers of E-26/010.000978/2019, E-26/010.001550/2019, E-26/211371/2019 and E-26/200153/2020, and CNPQ for the support with grant number 422614/2018-1. This study was also supported, in part, by the Coordenação de Aperfeiçoamento de Pessoal de Nível Superior - Brasil (CAPES) - Finance Code 001.

\section{Compliance with ethical standards}

Conflict of Interest The authors declare that they have no conflict of interest.

Open Access This article is licensed under a Creative Commons Attribution 4.0 International License, which permits use, sharing, adaptation, distribution and reproduction in any medium or format, as long as you give appropriate credit to the original author(s) and the source, 
provide a link to the Creative Commons licence, and indicate if changes were made. The images or other third party material in this article are included in the article's Creative Commons licence, unless indicated otherwise in a credit line to the material. If material is not included in the article's Creative Commons licence and your intended use is not permitted by statutory regulation or exceeds the permitted use, you will need to obtain permission directly from the copyright holder. To view a copy of this licence, visit http://creativecommons.org/licenses/by/4.0/.

\section{References}

1. Barakat, N.A.M., El-Newehy, M.H., Yasin, A.S., Ghouri, Z.K., Al-Deyab, S.S.: Ni\&Mn nanoparticles-decorated carbon nanofibers as effective electrocatalyst for urea oxidation. Appl. Catal. A Gen. 510, 180-188 (2016). https://doi.org/10.1016/j.apcat a.2015.11.015

2. Wang, D., Yan, W., Vijapur, S.H., Botte, G.G.: Electrochemically reduced graphene oxide-nickel nanocomposites for urea electrolysis. Electrochim. Acta 89, 732-736 (2013). https://doi. org/10.1016/j.electacta.2012.11.046

3. Vedharathinam, V., Botte, G.G.: Understanding the electrocatalytic oxidation mechanism of urea on nickel electrodes in alkaline medium. Electrochim. Acta 81, 292-300 (2012). https ://doi.org/10.1016/j.electacta.2012.07.007

4. Yan, W., Wang, D., Botte, G.G.: Nickel and cobalt bimetallic hydroxide catalysts for urea electro-oxidation. Electrochim. Acta 61, 25-30 (2012). https://doi.org/10.1016/j.elect acta.2011.11.044

5. Gao, X., Wang, Y., Li, W., Li, F., Arandiyan, H., Sun, H., Chen, Y.: Free-standing Ni-Co alloy nanowire arrays: efficient and robust catalysts toward urea electro-oxidation. Electrochim. Acta 283, 1277-1283 (2018). https://doi.org/10.1016/j.elect acta.2018.07.033

6. Yan, W., Wang, D., Diaz, L.A., Botte, G.G.: Nickel nanowires as effective catalysts for urea electro-oxidation. Electrochim. Acta 134, 266-271 (2014). https://doi.org/10.1016/j.elect acta.2014.03.134

7. Sayed, E.T., Eisa, T., Mohamed, H.O., Abdelkareem, M.A., Allagui, A., Alawadhi, H., Chae, K.J.: Direct urea fuel cells: challenges and opportunities. J. Power Sources 417, 159-175 (2019). https://doi.org/10.1016/j.jpowsour.2018.12.024

8. Silva, J.C.M., Piasentin, R.M., Spinacé, E.V., Neto, A.O., Baranova, E.A.: The effect of antimony-tin and indium-tin oxide supports on the catalytic activity of Pt nanoparticles for ammonia electro-oxidation. Mater. Chem. Phys. 180, 97-103 (2016). https ://doi.org/10.1016/j.matchemphys.2016.05.047

9. Simon-Várhelyi, M., Cristea, V.M., Luca, A.V.: Reducing energy costs of the wastewater treatment plant by improved scheduling of the periodic influent load. J. Environ. Manage. (2020). https:// doi.org/10.1016/j.jenvman.2020.110294

10. Yan, W., Wang, D., Botte, G.G.: Electrochemical decomposition of urea with Ni-based catalysts. Appl. Catal. B Environ. 127, 221-226 (2012). https://doi.org/10.1016/j.apcatb.2012.08.022

11. Wang, D., Yan, W., Botte, G.G.: Exfoliated nickel hydroxide nanosheets for urea electrolysis. Electrochem. Commun. 13, 1135-1138 (2011). https://doi.org/10.1016/j.elecom.2011.07.016

12. Barakat, N.A.M., Motlak, M., Ghouri, Z.K., Yasin, A.S., ElNewehy, M.H., Al-Deyab, S.S.: Nickel nanoparticles-decorated graphene as highly effective and stable electrocatalyst for urea electrooxidation. J. Mol. Catal. A Chem. 421, 83-91 (2016). https ://doi.org/10.1016/j.molcata.2016.05.011
13. Boggs, B.K., King, R.L., Botte, G.G.: Urea electrolysis: Direct hydrogen production from urine. Chem. Commun. (2009). https ://doi.org/10.1039/b905974a

14. Mohammed-Ibrahim, J., Xiaoming, S.: Recent progress on earthabundant electrocatalysts for hydrogen evolution reaction (HER) in alkaline medium to achieve efficient water splitting - a review. J. Energy Chem. 34, 111-160 (2019). https://doi.org/10.1016/j. jechem.2018.09.016

15. Banik, S., Mahajan, A., Kumar, Bhattacharya S.: Size control synthesis of pure Ni nanoparticles and anodic-oxidation of Butan-1-ol in alkali. Mater. Chem. Phys. (2019). https://doi.org/10.1016/j. matchemphys.2019.121747

16. Baranova, E.A., Cally, A., Allagui, A., Ntais, S., Wüthrich, R.: Nickel particles with increased catalytic activity towards hydrogen evolution reaction. Comptes Rendus Chim. 16, 28-33 (2013). https://doi.org/10.1016/j.crci.2012.02.003

17. Domínguez-Crespo, M.A., Ramírez-Meneses, E., Montiel-Palma, V., Torres Huerta, A.M., Dorantes, Rosales H.: Synthesis and electrochemical characterization of stabilized nickel nanoparticles. Int. J. Hydrog. Energy. 34, 1664-1676 (2009). https://doi. org/10.1016/j.ijhydene.2008.12.012

18. Chen, Z., Wu, R., Liu, Y., Ha, Y., Guo, Y., Sun, D., Liu, M., Fang, F.: Ultrafine Co nanoparticles encapsulated in carbon-nanotubes-grafted graphene sheets as advanced electrocatalysts for the hydrogen evolution reaction. Adv. Mater. 30, 1-10 (2018). https ://doi.org/10.1002/adma.201802011

19. Gorospe, A.E.G.B., Balela, M.D.L.: Ni-Co nanocomposites deposited on carbon fiber paper as an electrocatalyst towards hydrogen evolution reaction. Mater. Today Proc. 22, 255-261 (2020). https://doi.org/10.1016/j.matpr.2019.08.096

20. Seselj, N., Engelbrekt, C., Zhang, J.: Graphene-supported platinum catalysts for fuel cells. Sci. Bull. 60, 864-876 (2015). https ://doi.org/10.1007/s11434-015-0745-8

21. Boggs, B.K., Botte, G.G.: Optimization of Pt-Ir on carbon fiber paper for the electro-oxidation of ammonia in alkaline media. Electrochim. Acta 55, 5287-5293 (2010). https://doi. org/10.1016/j.electacta.2010.04.040

22. Kong, D., Wang, H., Lu, Z., Cui, Y.: CoSe2 nanoparticles grown on carbon fiber paper: an efficient and stable electrocatalyst for hydrogen evolution reaction. J. Am. Chem. Soc. 136, 4897-4900 (2014). https://doi.org/10.1021/ja501497n

23. Li, B., Song, C., Rong, J., Zhao, J., Wang, H.E., Yang, P., Ye, K., Cheng, K., Zhu, K., Yan, J., Cao, D., Wang, G.: A new catalyst for urea oxidation: NiCo2S4 nanowires modified 3D carbon sponge. J. Energy Chem. 50, 195-205 (2020). https://doi.org/10.1016/j. jechem.2019.12.018

24. Siqueira T.A.: Obtenção de camadas de difusao gasosa para célula a combustível do tipo PEM utilizando fibras curtas de carbono foto-funcionalizadas por luz UV (2012) http://hdl.handl e.net/10183/72931

25. Chen, I.H., Wang, C.C., Chen, C.Y.: Fabrication and structural characterization of polyacrylonitrile and carbon nanofibers containing plasma-modified carbon nanotubes by electrospinning. J. Phys. Chem. C 114, 13532-13539 (2010). https://doi.org/10.1021/ jp103993b

26. Zhou, H., Yu, Q., Peng, Q., Wang, H., Chen, J., Kuang, Y.: Catalytic graphitization of carbon fibers with electrodeposited Ni-B alloy coating. Mater. Chem. Phys. 110, 434-439 (2008). https:// doi.org/10.1016/j.matchemphys.2008.02.033

27. Pan, Y., Jia, R., Zhao, J., Liang, J., Liu, Y., Liu, C.: Size-controlled synthesis of monodisperse nickel nanoparticles and investigation of their magnetic and catalytic properties. Appl. Surf. Sci. 316, 276-285 (2014). https://doi.org/10.1016/j.apsusc.2014.07.203

28. Srimara, P., Chevapruk, T., Kumnorkaew, P., Muangnapoh, T., Vas-Umnuay, P.: Synthesis of Ni nanoparticles for solar selective 
absorber by chemical reduction method. Mater. Today Proc. 23, 720-725 (2020). https://doi.org/10.1016/j.matpr.2019.12.264

29. Simakova, I.L., Simonov, M.N., Demidova, Y.S., Yu Murzin, D.: Size-controlled reverse microemulsion synthesis of $\mathrm{Ni}$ and $\mathrm{Co}$ metal nanoparticles. Mater. Today Proc. 4, 11385-11391 (2017). https://doi.org/10.1016/j.matpr.2017.09.014

30. Li, P., Deng, G., Guo, X., Liu, H., Jiang, W., Li, F.: Preparation of nickel and Ni3Sn nanoparticles via extension of conventional citric acid and ethylene diamine tetraacetic acid mediated solgel method. J. Alloys Compd. 668, 159-168 (2016). https://doi. org/10.1016/j.jallcom.2016.01.203

31. Kristl, M., Dojer, B., Gyergyek, S., Kristl, J.: Synthesis of nickel and cobalt sulfide nanoparticles using a low cost sonochemical method. Heliyon. 3, 1-19 (2017). https://doi.org/10.1016/j.heliy on.2017.e00273

32. Xing, Y.T., Liu, L.Y., Franceschini, D.F., Nunes, W.C., Smith, D.J., Solorzano, I.G.: HRTEM and HRSTEM study of nanostructured materials prepared by pulsed laser deposition. Microsc. Microanal. 22, 2012-2013 (2016). https://doi.org/10.1017/s1431 927616010904

33. Neralla, S., Kotoka, R., Fialkova, S., Yarmolenko, S., Kvit, A., Pai, D., Sankar, J.: Effect of Fe and Ni nanoparticles on the structure and mechanical properties of alumina thin films. Compos. Part B Eng. 96, 255-263 (2016). https://doi.org/10.1016/j.compo sitesb.2016.04.045

34. Constantinescu, C., Dinescu, M., Physics, R.: Thin fi lms development by pulsed laser-assisted deposition 20, 43-56 (2014)

35. D.J. Wilson, R.L. Williams, R.C. Pond, Plasma modification of PTFE surfaces Part I : surfaces immediately following plasma treatment 385-396 (2001) https://doi.org/10.1002/sia.1065

36. Wang, D., Yan, W., Vijapur, S.H., Botte, G.G.: Enhanced electrocatalytic oxidation of urea based on nickel hydroxide nanoribbons. J. Power Sources 217, 498-502 (2012). https://doi.org/10.1016/j. jpowsour.2012.06.029

37. Zhan, S., Zhou, Z., Liu, M., Jiao, Y., Wang, H.: 3D NiO nanowalls grown on $\mathrm{Ni}$ foam for highly efficient electro-oxidation of urea. Catal. Today 327, 398-404 (2019). https://doi.org/10.1016/j.catto d.2018.02.049

38. Singh, R.K., Schechter, A.: Electrochemical investigation of urea oxidation reaction on $\beta \mathrm{Ni}(\mathrm{OH}) 2$ and $\mathrm{Ni} / \mathrm{Ni}(\mathrm{OH}) 2$. Electrochim. Acta 278, 405-411 (2018). https://doi.org/10.1016/j.elect acta.2018.05.049

39. Barbosa, J.R., Paranhos, C.H., Alves, O.C., Checca, N.R., Serna, J.P., Rossi, A.L., Silva, J.C.M.: Low loading platinum dispersed on $\mathrm{Ni} / \mathrm{C}$ nanoparticles as high active catalysts for urea electrooxidation reaction. Electrochim. Acta 355, 136752 (2020). https:// doi.org/10.1016/j.electacta.2020.136752

40. Machado, S.A.S., Avaca, L.A.: The hydrogen evolution reaction on nickel surfaces stabilized by $\mathrm{H}$-absorption. Electrochim. Acta
39, 1385-1391 (1994). https://doi.org/10.1016/0013-4686(94) E0003-I

41. Brown, I.J., Sotiropoulos, S.: Preparation and characterization of microporous Ni coatings as hydrogen evolving cathodes. J. Appl. Electrochem. 30, 107-111 (2000). https://doi. org/10.1023/A:1003888402752

42. Pimenta, M.A., Dresselhaus, G., Dresselhaus, M.S., Cançado, L.G., Jorio, A., Saito, R.: Studying disorder in graphite-based systems by Raman spectroscopy. Phys. Chem. Chem. Phys. 9, 1276-1291 (2007). https://doi.org/10.1039/b613962k

43. Tai, F.C., Lee, S.C., Wei, C.H., Tyan, S.L.: Correlation between ID/IG ratio from visible Raman spectra and sp2/sp3 ratio from XPS spectra of annealed hydrogenated DLC film. Mater. Trans. 47, 1847-1852 (2006). https://doi.org/10.2320/matertrans .47 .1847

44. Lacerda, J.N., Franceschini, D.F., Ponzio, E.A., Esteves, L.M., Guimarães, R.B.: Manganese oxide nanofoam prepared by pulsed laser deposition for high performance supercapacitor electrodes. Mater. Chem. Phys. (2020). https://doi.org/10.1016/j.matchemphy s.2019.122459

45. Zhou, X.C., Yang, X.Y., Fu, Z.B., Yang, Q., Yang, X., Tang, Y.J., Wang, C.Y., Yi, Y.: Single-crystalline ultrathin nanofilms of Ni aerogel with $\mathrm{Ni}(\mathrm{OH}) 2$ hybrid nanoparticles towards enhanced catalytic performance for ethanol electro-oxidation. Appl. Surf. Sci. 492, 756-764 (2019). https://doi.org/10.1016/j.apsus c. 2019.06 .210

46. Barakat, N.A.M., Amen, M.T., Al-Mubaddel, F.S., Karim, M.R., Alrashed, M.: NiSn nanoparticle-incorporated carbon nanofibers as efficient electrocatalysts for urea oxidation and working anodes in direct urea fuel cells. J. Adv. Res. 16, 43-53 (2019). https://doi. org/10.1016/j.jare.2018.12.003

47. Lan, R., Tao, S.: Preparation of nano-sized nickel as anode catalyst for direct urea and urine fuel cells. J. Power Sources 196, 50215026 (2011). https://doi.org/10.1016/j.jpowsour.2011.02.015

48. Gan, Q., Cheng, X., Chen, J., Wang, D., Wang, B., Tian, J., Isimjan, T.T., Yang, X.: Temperature effect on crystallinity and chemical states of nickel hydroxide as alternative superior catalyst for urea electrooxidation. Electrochim. Acta 301, 47-54 (2019). https ://doi.org/10.1016/j.electacta.2019.01.150

49. Quynh, T., Tran, N., Won, S., Ju, B., Hee, H.: CeO2-modified perovskite and MWCNT nanocomposite for electrocatalytic oxidation and detection of urea. J. Electroanal. Chem. 818, 76-83 (2018)

Publisher's Note Springer Nature remains neutral with regard to jurisdictional claims in published maps and institutional affiliations. 